\title{
Causes of and Solutions to the Challenges in fair Assessment in Semester System at Public Universities of the Punjab, Pakistan
}

\author{
Muhammad Pervaiz \\ Ph. D Scholar \\ Department of Education, UoS \\ mpervaiz220@gmail.com \\ Dr. Muhammad Sarwar \\ Professor \\ Department of Education, UoS \\ Dr. Ashfaque Ahmad Shah \\ Assistant Professor \\ Department of Education, UoS
}

\begin{abstract}
The purpose of this study was to identify the challenges to fair assessment in semester examination system, their causes and the solutions. One hundred and forty-four (144) university teachers were interviewed and 48 focus group discussions were conducted among the BS students in six public universities of the Punjab (Pakistan). The data were analyzed through thematic analysis technique. Findings of the study revealed that, in order to judge novice teachers' competence in assessment, universities did not ask for a professional teaching certification. Most of the university teachers appeared to be in need of having more competence in developing question papers and using different assessment techniques. Moreover, there was no proper mechanism of conduction and inservice training for the enhancement of teachers' essential skills for the fair assessment of students' learning outcomes. The course outlines were not covered completely within the stipulated time. Additionally, the university teachers had to perform multiple departmental duties, beside their teaching activities, compelling them compromises their classes. By force of circumstance, they teach and assess selective parts of the course outlines. The respondents suggested the development of a proper training mechanism for university teachers to make them capable of doing fair assessment and provision of required resources.
\end{abstract}

Keyword: Fair Assessment, Semester System, Examination, Question Papers, Assessment Challenges,

\section{Introduction}

The very need of a human being for judging the knowledge of several persons, at a time, and grading them according to their accomplishments caused the formation of examination system. The importance of this system gradually increased with the new developments in the field of education. In today's world, the examination system is perhaps the only accepted way to assess the acquired knowledge and judge the consequent learning outcomes of a large number of 
individuals simultaneously. The presence of a good examination system impels the students to work hard and helps promote a culture of healthy competition among them (Kiani, 2011; Umbreen, 2008). The concept of examination varies with the variation in its purposes that might be several in number: e.g. a) to check the progress of students on the basis of their results after a specific course of instruction; b) to make thoughtful judgments for their promotion to a higher grade; and c) to award scholarship or other benefits through a competitive examination either in the form of a written test or an oral method (Kiani, 2011).

During last decade, the semester examination system has been adopted by most of the universities. In this system, one year course is taught and assessed in two semesters and two year course is completed in four semesters (Ballantyne, 2003; Munshi, Javed, \& Hussain, 2012).The fundamental purpose of semester examination is to evaluate learning of students in a comprehensive, continuous and in-depth manner (N. Pokharel, 2018). This is a system where nearly 15 to 16 weeks of teaching is done two times in a year. Semester system has an objective and that is to improve the standard of education. The teachers are devoting more time and energy in their teaching and assessment(Biswas, 2007).

The effectiveness and success of semester examination system necessitates numerous conditions such as: a well-organized curriculum; regularity in arranging classes; constructive and well in time feedback on students work by the teachers; easy access of teachers for their students; course completion within specified period of time; provision of information resources for students; a highly reliable secrecy system in the examination; transparent evaluation; in time declaration of results of students' assessment (Aslam, Younis, Sheik, Maher, \& Abbasi, 2012).

The Draft National Educational Policy 2017 highlighted numerous dimensions and variables which influence quality of higher education - mechanism for educational assessment is one among them. Despite having spacious and better physical facilities in many of public sector universities, the academic excellence of their teaching faculty and the standard of their assessment systems is questionable. Particularly there are gaps and inconsistencies with respect to prevailing situations of examinations systems in different universities. The national education policy further highlighted that different universities have different scheme of studies and mechanism for conducting examination. The Universities have spelled out comprehensive criteria and principles of semester examination system for their regular students. It is unfortunate that university teachers 
from different departments loosely follow these criteria for fair assessment of students' accomplishment (GOP, 2017).

\subsection{Objective of Study}

The objective of the study was to identify the challenges to fair assessment in semester examination system, their causes and solutions in the public universities of Punjab, Pakistan.

\subsection{Significance of Study}

Present study will provide empirical evidence by identifying the challenges to fair assessment in semester examination system, which will in turn help Higher Education Commission (HEC) in reviewing the existing assessment policy and guide her in designing new policy as well. The university authorities may seek guidance in bridging the gap, if any, between semester examination policy and conduct practices. Heads of departments and departmental controllers of examinations may also get help in improving examination conduct practices and reporting of results in their respective departments. It may benefit university teachers in practicing quality assessment techniques.

\subsection{Delimitation of the Study}

Present study was delimited to BS program of public sector universities in the Punjab, Pakistan.

\section{Literature Review}

Assessment is generally seen as the major factor that promotes students' learning. In its various forms, it is among the most common activities that the teachers practice at all levels of education. At the same time, it is the most difficult activity to carry out satisfactorily(Bacquet, 2020). In simple words assessment can be used both; to evaluate students' learning achievements (assessment of learning) and; to enhance students' learning itself (assessment for learning) (Reinholz, 2016; Yorke, 2003). Boud, Lawson, and Thompson (2013) take it as a process of making judgments on the quality of students' performance.

Assessment is classified into different types according to its purposes. It is used to summarize the achievements of students in order to go for making a decision on awarding them some kind of certification i.e. summative assessment; and for providing students with feedback on their work with the notion to support their learning i.e. formative assessment (Falchikov, 2013; Yorke, 2003). 
Both of these fundamental aims are closely linked with each other and are applied to most of the assessment tasks to a variety of extents and at different levels of education (Gipps, 2011).Brown and Knight (2012)suggested that teachers should use a variety of assessment measures to determine more exactly what a student knows and does especially in semester examination system. Karami (2018)stated that sole objective of applying multiple assessment techniques is fair assessment of students" performance and learning.

Fair is a behavioural quality, specifically interacting or treating others without self-interest, partiality, or prejudice(Tierney, 2016). These three characteristics are the fundamental requirements for the fair assessment of students' learning. Unfortunately, the less existence of these qualities questioned the assessment practices and remain under investigation of most of the researchers in Pakistan and other under developing countries of world. For example Dahal (2018) conducted a case study to understand and analyse perception of students regarding semester system in Nepal. The researcher found incompatabilty of contents with the durtion of semester.The study conducted by Rahman (2013) in India revealed that the students were not satisfied with the semester examination system.

Simlarlyin Pakistan Khattak et al. (2015) evaluated the standpoints of students from Sarhad University and highlighted that unfair assessment and biasness in awarding marks to students were the major drawbacks of this system. Perveen and Saeed (2014) examined the current semester and annual examination practices at public sector universities of the Punjab. They found that annual examination is more secure and trustworthy right from the development of question papers to the compilation and declaration of results. Ayubbuzder and Ali (2013) studied the problems which were faced both by the teachers and students of public sector universities of the Punjab regarding semester examination system. They highlighted the problems like less alignment between teachers' instruction and the results of students, difficulty in time management for teachers and favoritism by the teachers. They also suggested a monitoring mechanism for teachers to make continuous assessment an effective one. Munshi et al. (2012) concluded that majority of the students disproved the semester examination system due to favouritism, biases and subjectivity in assessment. 


\subsection{Research Design}

\section{Methodology}

The qualitative research design was found suitable for the present study. The crosssectional survey was considered best fit for it because it provides information in a short span of time(Creswell, Klassen, Plano Clark, \& Smith, 2011; Mathiyazhagan \& Nandan, 2010).

\subsection{Population}

The population of the study consisted all students and teachers of public sector universities of the Punjab, Pakistan.

\subsection{Sample and Sampling Technique}

Multistage sampling technique was used to select a representative sample of the study in the following way.

- At first stage, 6 general public universities from the province Punjab were selected randomly.

- At second stage, eight departments were taken from each selected university (48 departments in total) to have an equal representation of both sciences and social sciences disciplines.

- At third stage, from each selected department, 3 faculty members (144 in total) and a group of at least 6 students for focus group discussion were selected (48 groups).

\subsection{Instrumentation}

Two types of research tools were used for data collection:

- Semi-structured interview schedule

- Focus group discussion guidelines

In pursuance of the development of research tools, two focus group discussions (FGDs) were held with the stakeholders (heads of departments, departmental controllers of examination, university teachers and students) to explore the relevant themes. The first FGD was conducted with two heads of departments, six teachers and two departmental controllers of examination from the departments of Chemistry and Education, University of Sargodha. The second FGD was organized with ten students (five from each) of the same departments. Findings of the analysis 
yielded several themes about the nature of challenges to fair assessment. Alongside the related literature was reviewed to explore relevant themes about nature of challenges to fair assessment.

The validation of tools was assured through experts' opinion. A three-point clarity scale (ranging from 'not clear' to 'clear') along with a relevance scale (ranging from 'irrelevant' to 'relevant') was added against the themes of each tool. Purpose of the clarity scale was provided to the experts so that they could make their judgments on the face and content validity of research tools. While, the relevance scale allowed the experts to report their opinion on construct validity of the tools i.e. whether or not a certain question in the tool was relevant to the construct of the study. A panel of ten HEC approved supervisors validated the tools. They were asked to mark a check in the relevant box against each scale that best represent their opinion about the clarity and relevance of each item. Their responses were analyzed by calculating percentage value for each item of the tools.

The clarity index and the relevance index were found by calculating arithmetic means of the scores. Items of the tools with clarity and relevance index below 0.8 were reformulated or replaced by the other items with similar concepts. During this process it was kept in mind that no significant changes in structure and properties of the tools were to be made. Afterwards, the tools were administered for pilot testing. The tools were pilot tested at four departments of the University of Sargodha. The researcher interviewed the three teachers from each department and one focus group discussion at each department was arranged amongst eight to ten students. The collected data were analyzed using thematic analysis technique. In the light of findings, and the suggestions given by the respondents and experts, the final version of tools was developed for actual study.

\subsection{Data Collection and Analysis}

The researcher personally visited the selected universities and collected the data. Thematic analysis technique was used to analyze the data which is one of the most common techniques of analysis in qualitative research. It emphasizes pinpointing, examining, and recording patterns (or "themes") within data -themes or patterns that are important to the description of a phenomenon (Creswell, 2012). The recorded interviews were transcribed and coded. Matrix of themes was developed on the basis of objectives of the study. 


\section{Data Analysis}

Table 1: Thematic Description of challenges to fair assessment Teachers' Perspective

\begin{tabular}{|c|c|c|}
\hline $\begin{array}{l}\text { Challenges to fair } \\
\text { assessment }\end{array}$ & Causes & Suggested Solutions \\
\hline \multirow[t]{3}{*}{$\begin{array}{l}\text { Inadequacy of } \\
\text { teachers } \\
\text { competence }\end{array}$} & $\begin{array}{l}\text { No compulsion of pre-service } \\
\text { professional training for recruitment - } \\
\text { universities do not require any } \\
\text { professional degree / certificate }\end{array}$ & $\begin{array}{l}\text { Provision of a professional } \\
\text { degree/certificate must be a pre- } \\
\text { requisite of selection criteria }\end{array}$ \\
\hline & $\begin{array}{l}\text { No proper mechanism for induction and } \\
\text { in-service teachers' training }\end{array}$ & $\begin{array}{l}\text { Development of a proper } \\
\text { mechanism for induction and } \\
\text { in-service training }\end{array}$ \\
\hline & $\begin{array}{l}\text { No effort by the teachers to update their } \\
\text { knowledge about latest assessment } \\
\text { techniques }\end{array}$ & $\begin{array}{l}\text { Development of a proper } \\
\text { mechanism for continuous in- } \\
\text { service training }\end{array}$ \\
\hline \multirow[t]{2}{*}{$\begin{array}{l}\text { Partial coverage of } \\
\text { course outlines }\end{array}$} & $\begin{array}{l}\text { Compulsion for teachers to perform } \\
\text { multiple departmental duties }\end{array}$ & $\begin{array}{l}\text { Minimising the workload of } \\
\text { teachers - decrease in number } \\
\text { of courses }\end{array}$ \\
\hline & $\begin{array}{l}\text { Incompatibility of course outlines with } \\
\text { stipulated time - un realistic course } \\
\text { outlines }\end{array}$ & $\begin{array}{l}\text { Alignment of course outlines } \\
\text { with stipulated time - } \\
\text { consideration of teachers' } \\
\text { feedback }\end{array}$ \\
\hline \multirow{3}{*}{$\begin{array}{l}\text { Non-professional } \\
\text { Behaviour of } \\
\text { Teachers }\end{array}$} & Sluggish behaviour of teachers towards & Inclusion of teachers' \\
\hline & students' assessment & $\begin{array}{l}\text { competence in assessment in } \\
\text { their promotion criteria }\end{array}$ \\
\hline & $\begin{array}{l}\text { Misuse of authority by the teachers - } \\
\text { teachers favour the students in } \\
\text { attendance and awarding marks who are } \\
\text { in their goods books or have relations }\end{array}$ & $\begin{array}{l}\text { Introduction of online } \\
\text { attendance system for students } \\
\text { Cross checking of answer } \\
\text { sheets by departmental } \\
\text { examination committee before } \\
\text { declaration of results }\end{array}$ \\
\hline \multirow{4}{*}{$\begin{array}{lr}\text { Difficulty in } \\
\text { smooth and fair } \\
\text { conduct } \\
\text { examination }\end{array}$} & Unavailability of examination halls & $\begin{array}{l}\text { Establishment of a separate } \\
\text { examination hall at each faculty }\end{array}$ \\
\hline & $\begin{array}{l}\text { Lack of coordination among different } \\
\text { committees/bodies }\end{array}$ & $\begin{array}{l}\text { Formulation of a proper } \\
\text { mechanism of communication } \\
\text { among different committees } \\
\text { and bodies }\end{array}$ \\
\hline & $\begin{array}{l}\text { No mechanism for quality assurance of } \\
\text { question papers }\end{array}$ & $\begin{array}{l}\text { Departmental examination } \\
\text { committee should wet the } \\
\text { question papers before the } \\
\text { conduct of examination }\end{array}$ \\
\hline & $\begin{array}{l}\text { Out-dated IT system - causing delay in } \\
\text { results }\end{array}$ & $\begin{array}{l}\text { Installation of sophisticated IT } \\
\text { gadgets }\end{array}$ \\
\hline
\end{tabular}


Table 1 Shows that the university teachers highlighted various challenges to fair assessment their causes and suggested solutions.

- University teachers are granted complete academic freedom regarding assessment of students' learning outcomes. Under the influence of their authority based on their liking and disliking towards some students, or their lack of competence hinders most of the time fair assessment of students' academic accomplishments.

- The students, who have blood relations or any kind of personal terms with the teachers, mostly misuse them for personal gains i.e. getting favorable marks.

- University teachers reported that they have to perform multiple departmental duties and a little time is left with them to prepare their lessons. Resultantly, they have to overlook some parts of course outlines. Inevitably, they assess their students on that chunk/s of course outlines.

- Course outlines are not compatible with stipulated period of time. Alongside, various kinds of issues hinder completion of course outlines. Yet they are supposed to develop a question paper inclusive of complete course outlines.

- University teachers feel that there is no pre-requisite professional degree or certificate for the teachers to teach and evaluate the students. In addition to it, There is no proper mechanism of induction training in the universities. So, university teachers are not sufficiently able to use different assessment techniques. As a result, the quality of question papers and subsequently students' assessment is compromised.

- Each department in the university is itself responsible for conducting the examination. However, university teachers alarmingly proclaimed that the departments have not any separate examination halls. They are compelled to use classrooms as examination halls.

- The university and departmental administration bind teachers to complete their credit hours within the stipulated time frame. They are also demanded to fulfill additional departmental responsibilities. As a result, they either overlook some parts of course outlines or unable to teach the content properly. Consequently, they assess their students on that chunk/s of course outlines.

- In semester system, several committees and administrative bodies work side by side. Whereas, it is a matter of fact that there is no proper mechanism for their coordination. This lack of 
coordination among different committees and bodies create problems in fair assessment of students.

- No mechanism for quality assurance of question papers exists. Consequently teachers do not bother to update their knowledge and skills as to how a valid question paper is prepared.

- Some of the university teachers, due to their sluggish attitude, do not take the students' assessment a serious job.

- Use of information technology is key component of the semester system. Whereas, the quantity and quality of IT gadgets being used in the universities do not meet the present day requirements.

- Experience and high competency level can increase the quality of assessment but unfortunately, the teachers in semester system are less competent and less experienced especially in the process of assessment.

- There is no mechanism of teacher training for the quality assessment of the students. University teachers suggested following solutions:

- A proper mechanism of university teachers' training on students' assessment should be introduced. An experience sharing and training forum may be established for this purpose.

- Departmental examination committee should crosscheck the answer sheets before declaration of results.

- Provision of a professional degree/certificate must be an integral component of the selection criteria.

- A separate examination hall should be established at each faculty level.

- Workload of teachers needs to be minimized by decreasing the number of mandatory courses for each teacher.

- Sufficient number of sophisticated IT gadgets should be installed in the laboratories

- Online attendance system may be introduced to minimize the favoritism 
Table 2: Thematic Description of challenges to fair assessment Students Perspective.

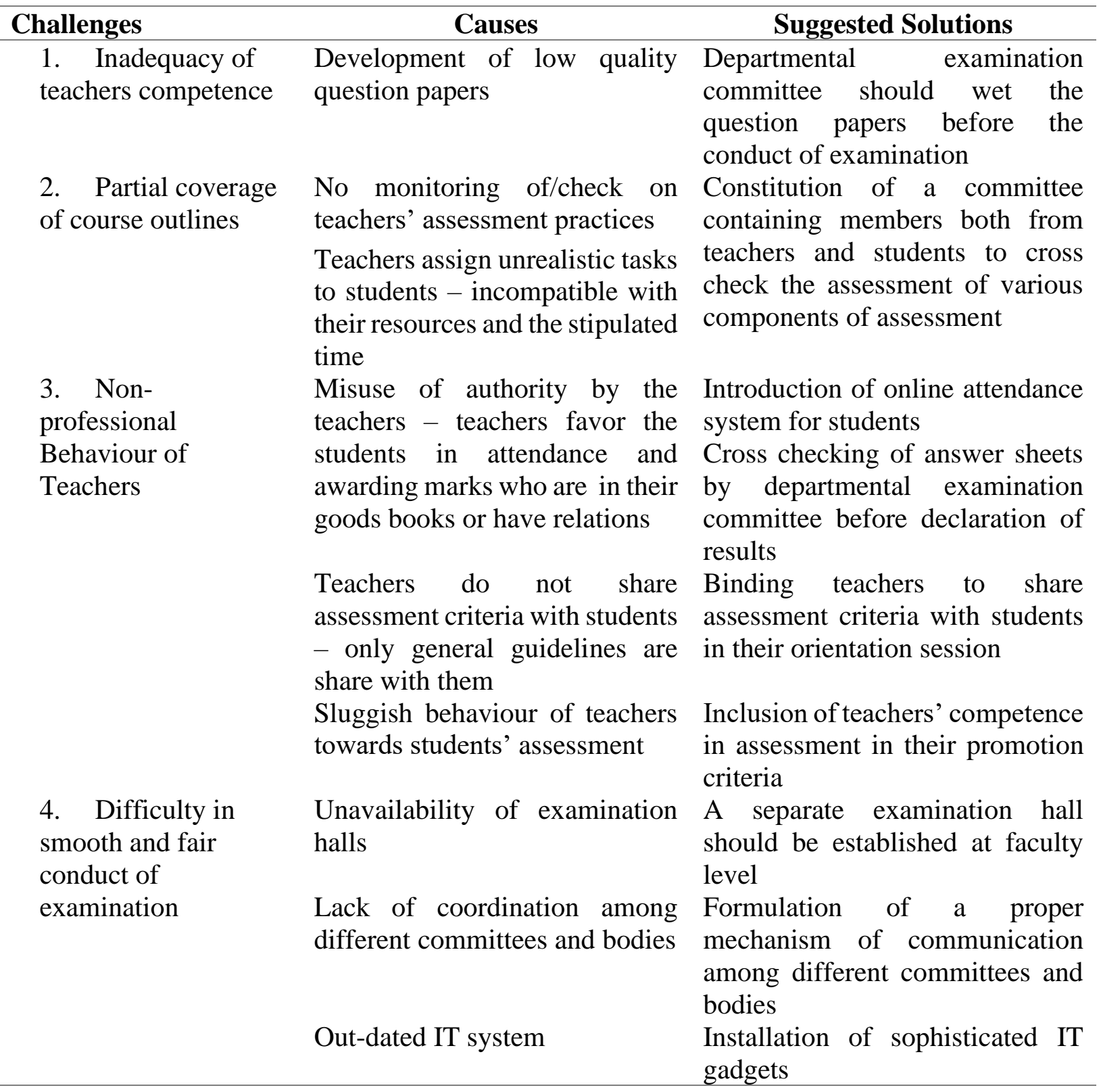

Table 2 shows the challenges and their causes to fair assessment in semester examination system highlighted by the students:

- Effective assessment of students' learning is a time taking process. However, teacher have limited time for this critical job.

- In this system there is no check on assessment practices of university teachers. They do not even bother to complete course outlines. They only teach selective content and develop question papers accordingly. 
- The students believe that in semester system teachers' autonomy is unjustified. It is only a teacher centered system.

- University teachers often assign unrealistic task to the students which are incompatible with the available resources and the time allocated for these tasks.

- At times it so happens that the question papers made by university teachers are of low quality that is the question papers are unnecessarily lengthy; language is not clear; validity is compromised; and they are non-representative of the content taught to students etc.

The students suggested following solution of prevailing challenges to fair assessment in semester examination system:

- Departmental examination committee should wet the question papers before the conduct of examination

- Cross checking of answer sheets by departmental examination committee before declaration of results

- Departmental examination committee and the representatives of students should cross check the assessment by the teachers vis-a-vis the different components of assessment

- Online attendance system for students may be introduced

- Teachers should be bound to share assessment criteria with students in their orientation session

- The level of teachers' competence in assessment may be an essential component of their promotion criteria

- A separate examination hall should be established at each faculty level

- Formulation of a proper mechanism of communication among different committees and bodies

- Installation of sophisticated IT gadgets

- Duration of semester should be increased

- Assessment specific training of university teachers should be organized on regular basis. 


\section{Discussion}

Findings of the study revealed four major challenges to fair assessment in semester system among public universities of the Punjab. These challenges include inadequate competence level of teachers in assessment, their non-professional behavior, partial coverage of course outlines, and difficulty in smooth conduct of examination. In addition to it, students proclaim that under these circumstances the teachers get to develop low quality question papers the undercurrent to the challenges in fair assessment. The same was found by Perveen and Saeed (2014), Munshi et al. (2012), Ayubbuzder and Ali (2013) who found the malfunctioning of semester examination system in terms of low quality assessment of students assignments and the development of invalid question papers by the university teachers - as an indicator of their less competence in assessment.

This situation is worsened by the non-professional behavior of the teachers. Universities have granted academic freedom to their teachers particularly with respect to students' assessment often with no check and balance on it. Resultantly, they misuse their authority by favoring some students in attendance and in awarding them high marks. Sometimes, under the influence of their authority, they victimize some of the students by awarding comparatively low marks. These findings were consistent with the work ofKhattak et al. (2015), Perveen and Saeed (2014) and Ayubbuzder and Ali (2013), and Munshi et al. (2012).

The challenge of partial coverage of course outlines in teaching and assessment is mostly due to the reason that the existing course outlines are unrealistic and mismatched with the stipulated time frame. The university teachers are bound to teach and assess the complete course outlines, under rules, however it was found that university rules in this regard were being violated under the cover of certain reasons. The violation of rules and regulation in assessment was authenticated by the findings of Dahal (2018); Perveen and Saeed (2014), Munshi et al. (2012), Ayubbuzder and Ali (2013).

\section{Conclusions}

Findings of the study reveal four major challenges to fair assessment in semester system which include inadequate competence level of teachers in assessment, their non-professional behavior, partial coverage of course outlines, and difficulty in smooth conduct of examination. Both the teachers and students are of the view as the fundamental reason of inadequate competence of teachers in assessment is that universities do not require any professional degree/certificate at 
the time of their recruitment. Besides this there is no proper mechanism of induction and in-service training for university teachers regarding assessment. Moreover, teachers do not update their knowledge about latest assessment techniques. In addition to it, students proclaim that under these circumstances the teachers get to develop low quality question papers the undercurrent to the challenges in fair assessment.

This situation is aggravated by the non-professional behavior of teachers. Universities have granted academic freedom to their teachers particularly with respect to students' assessment often with no check and balance on it. Resultantly, university teachers do not bother to share the assessment criteria with their students. During teaching they assign unrealistic tasks to students' in-compatible with the available resources and specified time. They misuse their authority by favoring some students in attendance and in awarding them high marks. Sometimes, under the influence of their authority, they victimize some of the students by awarding comparatively low marks.

The challenge of partial coverage of course outlines in teaching and assessment is mostly due to the reason that the existing course outlines are unrealistic and mismatched with the stipulated time frame. Besides this, the university teachers have to perform multiple departmental duties, along with their teaching activities, compelling them to compromise their classes or their preparation for classes. Under such circumstances, they teach and assess selective parts of the course outlines and focus on completing their credit hours. The difficulty in smooth and fair conduct of examination is another challenge to ensure fair assessment. The underlying reasons to this challenge are unavailability of separate examination halls; non-existence of any mechanism for quality assurance of question papers; insufficiency of modern IT gadgets - causing delay in result declaration; and lack of coordination among different committees or bodies.

The respondents suggested the development of a proper training mechanism for university teachers to make them capable of doing fair assessment. They proposed alignment of course outlines with the stipulated time frame; extrication of university teachers from extra duties; construction of separate examination halls in each department; installation of up-to-date IT system; and most importantly, check and balance on the undue academic freedom of teachers to avoid bias assessment. 


\subsection{Recommendations}

Inadequate competence of university teachers in assessment was found the major challenge to fair assessment because universities do not require any professional degree or certificate as part of appointment criteria for university teachers. Hence it is recommended that higher education commission and university authorities may include at least six months diploma in assessment in their appointment criteria for university teachers which was also recommended by National Educational Policy 2009 for the recruitment of lecturer through public service commission.

\section{References}

Aslam, H. D., Younis, A., Sheik, A. A., Maher, M., \& Abbasi, Z. A. (2012). Analyzing factors affecting students' satisfaction regarding semester system in universities of Pakistan. Journal of American Science, 8(10), 163-170.

Ayubbuzder, M., \& Ali, A. (2013). Assessment of students' learning achievements under semester system in Pakistan. Journal of Basic and Applied Scientific Research, 3(6), 79-86.

Bacquet, J. N. (2020). Implications of Summative and Formative Assessment in Japan-A Review of the Current Literature. International Journal of Education and Literacy Studies, 8(2), 28-35.

Ballantyne, C. (2003). Online evaluations of teaching: An examination of current practice and considerations for the future. New directions for teaching and learning, 2003(96), 103-112.

Biswas, R. R. (2007). Accelerating remedial math education: How institutional innovation and state policy interact. Achieving the Dream policy brief for Jobs for the Future, 1-11.

Boud, D., Lawson, R., \& Thompson, D. G. (2013). Does student engagement in self-assessment calibrate their judgement over time? Assessment \& Evaluation in Higher Education, 38(8), 941-956.

Brown, S., \& Knight, P. (2012). Assessing learners in higher education: Routledge.

Creswell, J. W. (2012). Educational research: Planning, Conducting, and Evaluating Quantitative and Qualitative Research (4th ed.). Boston: Pearson Education Inc.

Creswell, J. W., Klassen, A. C., Plano Clark, V. L., \& Smith, K. C. (2011). Best practices for mixed methods research in the health sciences. Bethesda (Maryland): National Institutes of Health, 2013, 541-545.

Dahal, R. K. (2018). Students' Perception towards Master of Business Studies (MBS) Semester System: A Case Study of Nepal Commerce Campus. Pravaha, 24(1), 181-195.

Falchikov, N. (2013). Improving assessment through student involvement: Practical solutions for aiding learning in higher and further education: Routledge.

Gipps, C. (2011). Beyond Testing (Classic Edition): Towards a theory of educational assessment: Routledge. 
GOP. (2017). National Education Policy 2017-2025. Islamabad: Ministry of Federal Education and Professional Training Government of Pakistan.

Karami, H. (2018). Fairness issues in educational assessment: Routledge.

Khattak, H., Mughal, A. W., Marwat, M. K., Jan, S., Waseem, M., \& Bibi, S. (2015). Perception of the students of Sarhad university regarding the impact of different systems of examination upon their academic performance. Asian Journal of Management Sciences \& Education, 4(2), 43-51.

Kiani, M. A. H. (2011). A study to evaluate the examination system at grade-v in the Punjab, based on Solo Taxonomy. FOUNDATION UNIVERSITY COLLEGE OF LIBERAL ARTS AND SCIENCES RAWALPINDI.

Mathiyazhagan, T., \& Nandan, D. (2010). Survey research method. Media Mimansa, 4(1), 34-45.

Munshi, D. P., Javed, M., \& Hussain, D. I. (2012). Examination In Semester System: What Is Observation Of Faculty And Students? The Sindh University Journal of Education-SUJE, 41.

N. Pokharel, M. J. a. S. S. (2018). Perception Study of Teachers And Students regarding the Functionality of Semester System In Agriculture. International Journal of Scientific \& Engineering Research, 9(9), 1074-1081.

Perveen, U., \& Saeed, M. (2014). A Comparative Study of Examination Practices in Annual and Semester System in Public Sector Universities of the Punjab Pakistan. International Journal of Academic Research in Progressive Education and Development, 3(01), 243254.

Rahman, T. P. M. A. (2013). Perception of students and teachers towards semester system: A study in some selected degree colleges of Nagaon Town of Nagaon district of Assam. Perception, $4(1)$.

Reinholz, D. (2016). The assessment cycle: a model for learning through peer assessment. Assessment \& Evaluation in Higher Education, 41(2), 301-315.

Tierney, R. (2016). Fairness in educational assessment. Encyclopedia of educational philosophy and theory, 1-6.

Umbreen, I. (2008). A study on Social Acceptability of Levels of Education System and its Implications in Pakistan. PMAS-Arid Agriculture University, Rawalpindi.

Yorke, M. (2003). Formative assessment in higher education: Moves towards theory and the enhancement of pedagogic practice. Higher education, 45(4), 477-501. 